\title{
Acute Blockade of Corticosterone Secretion Decreases the Psychomotor Stimulant Effects of Cocaine
}

\author{
M. Marinelli, Pharm. D., Françoise Rougé-Pont, Ph.D., Cécile De Jesus-Oliveira, B.S., \\ Michel Le Moal, M.D., Ph.D., and Pier V. Piazza, M.D., Ph.D.
}

Previous reports have shown that long-term blockade of corticosterone secretion, by either adrenalectomy or repeated treatment with an inhibitor of corticosterone synthesis, metyrapone, profoundly reduces sensitivity to drugs of abuse. In this report we investigated whether acute blockade of corticosterone secretion has similar effects. Animals received a single injection of metyrapone $(50 \mathrm{mg} /$ $\mathrm{kg} \mathrm{SC)}$ and were tested for their locomotor response to cocaine (15 mg/kg IP) 3 hours later. Acute metyrapone treatment reduced the locomotor response to cocaine by

KEY WORDS: Corticosterone; Cocaine; Locomotor response; Psychomotor effects; Metyrapone

Three lines of evidence indicate that corticosterone, the major glucocorticoid hormone in the rat, increases the psychomotor and reinforcing effects of psychostimulant drugs (for review, see Piazza et al. 1991a; Piazza and Le Moal 1996). First, there is a positive correlation between corticosterone secretion and sensitivity to the reinforcing effects of psychostimulants (Piazza et al. 1991b). Second, administration of corticosterone before an amphetamine self-administration session increases the reinforcing properties of the drug (Piazza et al. 1991b). Third, chronic suppression of corticosterone secretion either by

From the Department of Adaptive Behavioral Psychobiology, INSERM U 259, University of Bordeaux II, Bordeaux, France.

Address correspondence to: Dr. Pier Vincenzo Piazza, INSERM U 259, University of Bordeaux II, Rue Camille Saint-Saëns, 33077 Bordeaux cedex, France.

Received January 4, 1996; revised May 24, 1996; accepted June 11, 1996 about $50 \%$, and this effect was reversed by corticosterone $(20 \mathrm{mg} / \mathrm{kg} \mathrm{SC})$. The behavioral effects of these treatments paralleled changes in plasma corticosterone levels 20 minutes after an injection of cocaine. Despite the differences in behavior and corticosterone levels, the brain levels of cocaine in these groups did not differ. These results indicate that the behavioral effects of cocaine can be modified by an acute pharmacological manipulation of corticosterone secretion. (C) 1997 American College of Neuropsychopharmacology Neuropsychopharmacology 16:156-161, 1997]

adrenalectomy or chronic treatment with an inhibitor of corticosterone synthesis, metyrapone, decreases the psychomotor and reinforcing effects of psychostimulants (Marinelli et al. 1994; Piazza et al. 1994), and prevents the stress-induced sensitization of these effects (Deroche et al. 1992, 1993, 1995; Rougé-Pont et al. 1995). Conversely, replacement of corticosterone reverses these effects (Marinelli et al. 1994; Deroche et al. 1995).

In this report we further investigated the influence of corticosterone on sensitivity to psychostimulants. In particular, we aimed to determine whether the behavioral effects of a psychostimulant drug can be modulated by acute manipulations of corticosterone secretion. Previous reports have shown that long-term (minimum 1 week), suppression of corticosterone secretion reduces the sensitivity to the behavioral effects of cocaine, but it is not known whether an acute inhibition of corticosterone secretion has similar effects. For this purpose, we determined the effects on the locomotor response to cocaine of a single injection of metyrapone (2 methyl-1,2-di-3pyridyl-1-propanone) administered 3 hours before the 
psychostimulant drug. We also further characterized the effects of metyrapone, as the specificity of its effects has not yet been investigated. In particular we determined whether (1) corticosterone administration can reverse the effects of metyrapone; and (2) the effects of metyrapone are secondary to changes in cocaine availability in the brain. Finally, we explored the effects of metyrapone on cocaine-induced corticosterone secretion.

\section{MATERIALS AND METHODS}

\section{Animals}

Male Sprague-Dawley rats (Iffa-Credo, Lyon, France) weighing 280 to $300 \mathrm{~g}$ were individually housed with ad libitum access to food and water. A 14:10 light-dark cycle (lights on at 6:00 AM) was maintained in the animal room, and temperature $\left(22^{\circ} \mathrm{C}\right)$ and humidity $(60 \%)$ were kept constant. Animals were allowed at least 1 week to acclimatize to the animal room before we started any experimental manipulation.

\section{Locomotor Activity and Constitution of Experimental Groups}

Locomotor activity was measured automatically in a circular corridor (10 $\mathrm{cm}$ wide and $70 \mathrm{~cm}$ in diameter) by quantifying interruptions of photocell beams located at the perpendicular axis of the apparatus. As it has been shown that locomotor response to novelty is correlated to sensitivity to the psychomotor effects of drugs (Piazza et al. 1989; Hooks et al. 1991), we ensured a homogeneous distribution of this factor by initially prescreening the animals for their locomotor response to novelty (Piazza et al. 1991b) and then balancing the groups for this response. Experiments began 7 to 10 days after the response to the novelty test.

\section{Drugs and Drug Administration}

For all experiments, metyrapone (Sigma) was dissolved in a vehicle solution containing distilled water and $7 \%$ of Tween 80 and was administered SC at a dose of 50 $\mathrm{mg} / \mathrm{kg}$ in a $2-\mathrm{ml} / \mathrm{kg}$ volume. Similar doses have previously been shown to significantly reduce corticosterone synthesis (Stein and Sapolsky 1988; Murison et al. 1989). Corticosterone (Sigma) was suspended in sesame oil and injected SC at a dose of $20 \mathrm{mg} / \mathrm{kg}$ in a $1-\mathrm{ml} / \mathrm{kg}$ volume. Cocaine $\mathrm{HCl}$ (Coopération Pharmaceutique Française. France) was dissolved in $0.9 \% \mathrm{NaCl}$ solution (saline) and injected IP at a dose of $15 \mathrm{mg} / \mathrm{kg}$ in a $1-\mathrm{ml} / \mathrm{kg}$ volume.

\section{Corticosterone Assay}

Plasma corticosterone was measured by radioimmunoassay (RIA kit, ICN Biomedicals) using a highly specific corticosterone antiserum with a detection threshold of $0.1 \mu \mathrm{g} / 100 \mathrm{ml}$.

\section{Cocaine Assay}

Brains were separated from the cerebellum and sonicated in acetonitrile. Cocaine content was measured in the supernatant by high-performance liquid chromatography (HPLC) coupled with UV detection (Shimadzu-SPD-A, $\lambda=235 \mathrm{~nm}$ ). The chromatographic system consisted of a Milton Roy constametric pump, a refrigerated automatic injector (CMA200 Carnegie Medicine. Sweden), a precolumn, and a C18 Kromasil column. Results are expressed as $\mu \mathrm{g} / \mathrm{g}$ of brain.

\section{Effects of Metyrapone on the Locomotor Response to Cocaine}

Two groups of animals ( $n=7$ each) received an injection of either vehicle (VEHICLE group) or metyrapone (METY group) at 9:00 AM. One hour later, they were placed in the circular corridor. After 2 hours of habituation to the apparatus, all animals received an injection of saline, and their locomotor response was recorded for 2 hours over 10-min intervals. Animals were then returned to their home cage. Four days later, the animals underwent the same procedure, but instead of saline, they received an injection of $15 \mathrm{mg} / \mathrm{kg}$ cocaine, and their behavior was recorded for 2 hours. Four days after the cocaine test, the experiment was repeated, but on this occasion animals in the METY group received both metyrapone and corticosterone 1 hour prior to being placed in the circular corridor (METY + CORT), whereas rats in the VEHICLE group received vehicle and oil. The locomotor response to cocaine was again recorded as described.

\section{Effects of Metyrapone on the Plasma Levels of Corticosterone and on the Brain Levels of Cocaine}

To determine corticosterone levels in response to an injection of cocaine, a different set of animals underwent the same treatments as described to form the following groups: VEHICLE $(n=8)$, METY $(n=8)$, and METY + CORT $(n=6)$. Animals were placed in the circular corridor 1 hour after having received the assigned treatment. After 2 hours of habituation to the apparatus, they received an injection of cocaine. Twenty minutes later, they were sacrificed by decapitation. Trunk blood was collected for corticosterone assay. At the same time, brains were quickly removed, placed in dry ice, and stored at $-80^{\circ}$ until assayed for levels of cocaine.

\section{Statistical Analysis}

Data were analyzed with an analysis of variance (ANOVA) considering the treatment as between-factor. 


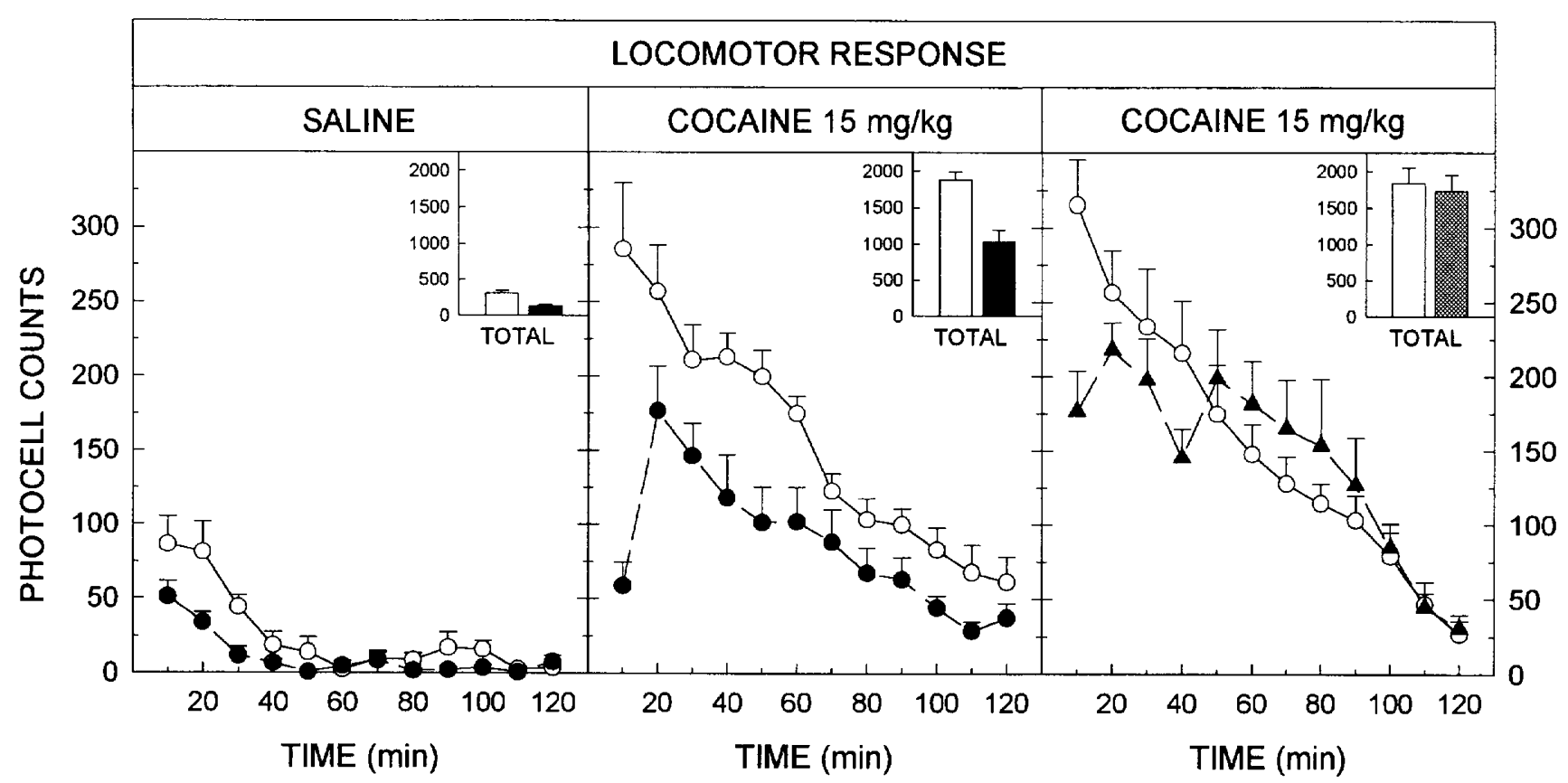

Figure 1. Effect of metyrapone ( $50 \mathrm{mg} / \mathrm{kg}$, solid circles or solid bars) on the locomotor response to saline (left panel) and cocaine (center panel), and of metyrapone $(50 \mathrm{mg} / \mathrm{kg}$ ) plus corticosterone $(20 \mathrm{mg} / \mathrm{kg}$, solid triangles and grey bars) on the locomotor response to cocaine (right panel). Each point represents the mean \pm SEM of the locomotor activity over 10 minutes. Bars represent the mean \pm SEM of the total locomotor activity over 1 hour of testing. Metyrapone treatment significantly reduced the locomotor response to both saline $[F(1,12)=15.62, p<.01]$ and cocaine $[F(1,12)=18.95, p<.001]$. There was, however, a greater reduction in the locomotor response to cocaine than in the saline, as indicated by a significant analysis of covariance considering the response to saline as a covariate $[F(1,11)=16.49, p<.01]$. Corticosterone administration reversed the effects of the metyrapone treatment on the response to cocaine. Thus (right panel), animals treated with metyrapone no longer differed from the vehicle group (open circles and bars) when they were concomitantly administered corticosterone $[F(1,12)=0.15, p>.7]$.

The Newman-Keuls test was used for post hoc analysis where necessary. Because metyrapone reduced the locomotor response to a saline injection, the response to the cocaine injection was also subjected to an analysis of covariance (ANCOVA) considering the response to saline as covariate. To analyze the effects of concomitant administration of corticosterone and metyrapone on the locomotor response to cocaine, a further analysis was performed considering the day of testing (first versus second cocaine injection) for the vehicle or metyrapone groups as withinfactor.

\section{RESULTS}

\section{Effects of Metyrapone on the Locomotor Response to Cocaine}

Figure 1 shows that metyrapone treatment significantly reduced the locomotor response to both saline [left panel, $F(1,12)=15.62, p<.01]$ and cocaine [center panel, $F(1,12)=18.95, p<.001]$. There was, however, a greater reduction in the locomotor response to cocaine than to saline, as indicated by the ANCOVA considering the response to saline as a covariate $[F(1,11)=16.49, p<.01]$.
Corticosterone administration reversed the effects of metyrapone on the response to cocaine (right panel). Thus, animals treated with metyrapone no longer differed from the vehicle group when they concomitantly received corticosterone $[F(1,12)=0.15, p>$.7]. Furthermore, animals in the vehicle group did not differ over the last 2 days of testing $[F(1,6)=0.046, p>.8]$, whereas the locomotor response to cocaine was significantly higher in rats treated with corticosterone plus metyrapone than in rats given metyrapone alone $[F(1,6)=9.10, p<.05$; compare the center and right panels on Figure 1].

\section{Effects of Metyrapone on Corticosterone Levels}

There were significant group differences in plasma levels of corticosterone following a cocaine injection $[F(2,20)=$ $4.17, p<.05$; Figure 2]. Metyrapone treatment significantly decreased plasma corticosterone levels relative to the vehicle controls $(p<.05)$. The administration of corticosterone reversed the effects of metyrapone (mety + cort versus mety, $p<$. 05) and resulted in levels of corticosterone that did not differ from those in control animals (vehicle versus mety + cort, NS). 


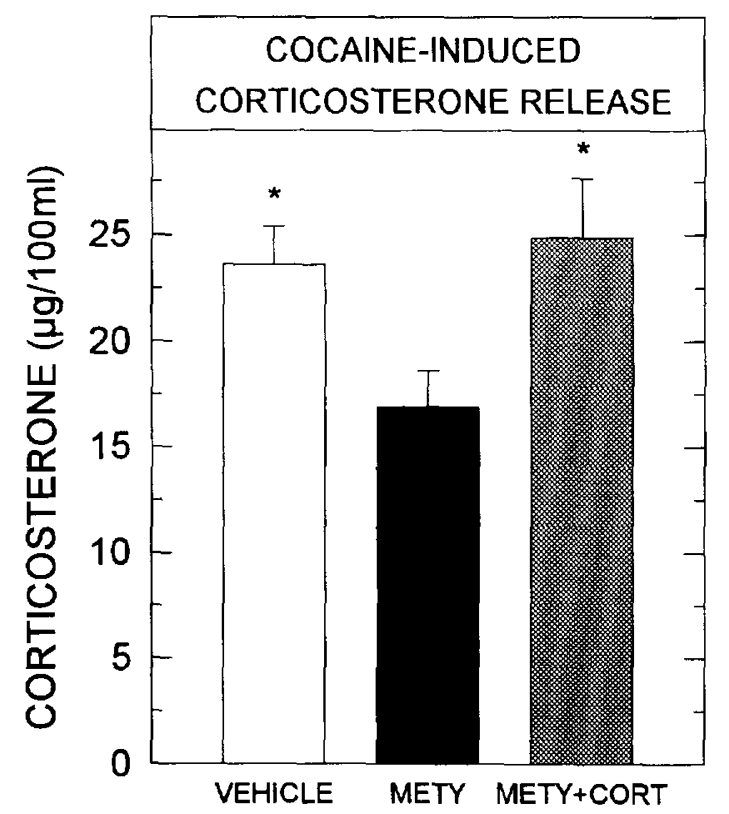

Figure 2. Effects of metyrapone $(50 \mathrm{mg} / \mathrm{kg})$ and concomitant administration of metyrapone $(50 \mathrm{mg} / \mathrm{kg}$ ) and corticosterone $(20 \mathrm{mg} / \mathrm{kg})$ on plasma levels of corticosterone in response to an injection of cocaine $(15 \mathrm{mg} / \mathrm{kg})$. Each value represents the mean \pm SEM. Metyrapone treatment (METY) significantly decreased plasma corticosterone levels in response to the cocaine injection. The administration of corticosterone (METY + CORT) reversed the effects of metyrapone and resulted in levels of corticosterone that did not differ from those in control animals (VEHICLE). ${ }^{*} p<.05$ compared to metyrapone-treated animals.

\section{Effects of Metyrapone on the Brain Levels of Cocaine}

There were no group differences in the brain concentrations of cocaine 20 minutes after the injection of the $\operatorname{drug}[F(2,20)=0.29, p>.74$; Figure 3].

\section{DISCUSSION}

Our results indicate that an acute pharmacological blockade of corticosterone secretion reduces sensitivity to cocaine. The locomotor response to cocaine was profoundly reduced within 3 hours of a single administration of the corticosterone synthesis inhibitor metyrapone. These changes in cocaine-induced locomotion were paralleled by significant changes in corticosterone secretion. Circulating levels of corticosterone following a cocaine injection were significantly reduced after metyrapone treatment. The effect of metyrapone on cocaine-induced locomotion was corticosterone-dependent because it was reversed if animals received corticosterone at the same time as they received metyrapone.

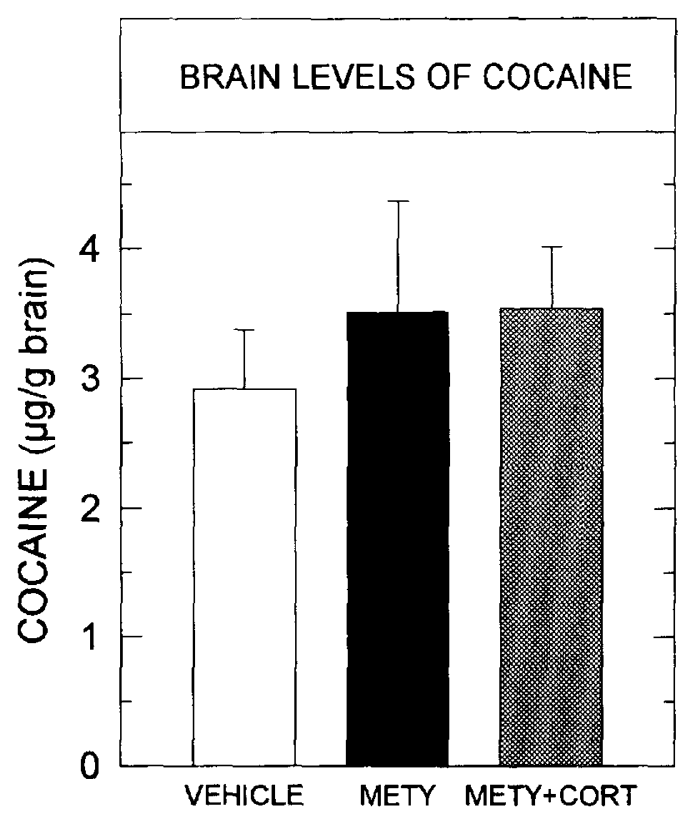

Figure 3. Effects of metyrapone $(50 \mathrm{mg} / \mathrm{kg})$ and concomitant administration of metyrapone $(50 \mathrm{mg} / \mathrm{kg})$ and corticosterone $(20 \mathrm{mg} / \mathrm{kg})$ on brain levels of cocaine. Brain concentrations of cocaine 20 minutes after the injection of the drug did not differ in animals receiving metyrapone (METY) or metyrapone plus corticosterone (METY + CORT) compared to control rats (VEHICLE) $[F(2,20)=0.29, p>.74]$.

These results confirm previous findings suggesting that corticosterone facilitates the action of psychostimulant drugs and extend them to showing that an acute decrease in corticosterone secretion can have similar effects as chronic blockade in reducing the psychomotor activating effects of psychostimulant drugs, as for example by adrenalectomy (Marinelli et al. 1994) or repeated metyrapone treatment (Piazza et al. 1994; RougéPont et al. 1995).

One of the possible mechanisms by which circulating levels of corticosterone modify the behavioral response to cocaine could be by changing the amount of cocaine that reaches the brain. We found, however, that this was not the case because neither metyrapone treatment nor corticosterone replacement had any effects on the brain concentrations of cocaine.

Corticosterone may modulate sensitivity to psychostimulants through an action on mesencephalic dopaminergic neurons, which are thought to mediate psychomotor activating effects and reinforcing effects of psychostimulant drugs (for review, see Fibiger and Phillips 1988; Koob and Bloom 1988; Wise and Rompre 1989; Le Moal and Simon 1991). Dopaminergic mesencephalic neurons have corticosterone receptors (Häfstrand et al 1986), and an increase in glucocorticoids has been shown to reduce dopamine catabolism (Veals et al. 1977; Rothchild et al. 1985) and to increase dopamine release (Imperato et al. 1989; Piazza et al. 1993), whereas the reduction of cortico- 
sterone has the opposite effects (Caesar et al. 1970; Rastogi and Singhal 1978; Rougé-Pont et al. 1995). An interaction between corticosterone and mesolimbic dopaminergic neurons in modulating the behavioral effects of drugs also is suggested by the observation that the effects of corticosterone on cocaine-induced locomotion are similar when cocaine is injected either systemically or in the nucleus accumbens (Marinelli et al. 1994). The ability of cocaine to induce locomotor activity when injected into the nucleus accumbens depends on an increase in dopamine concentrations in this structure (Delfs et al. 1990).

The effect of corticosterone on the psychomotor activating effects of cocaine could also involve other neurotransmitters. For instance, GABA, serotonin (5-HT), opioids, and excitatory amino acids have been shown to modulate dopamine-mediated responses to psychostimulants (Scheel-Krüger et al. 1981; Kalivas et al. 1989; Kelland et al. 1990; Pulvirenti et al. 1991) and are influenced by glucocorticoids. The binding capacity of GABA receptors in vitro is potentiated by glucocorticoids (Majewska et al. 1986; Majewska 1987; Sutanto et al. 1989); furthermore glucocorticoids modulate 5-HT receptor density (Biegon et al. 1985; De Kloet et al. 1986; Martire et al. 1989) and potentiate glutamatergic transmission (Tischler et al. 1988; Sapolsky 1990).

In conclusion, our results indicate that the behavioral effects of cocaine can be modified by acute pharmacological manipulation of corticosterone secretion. These findings extend our knowledge on the involvement of glucocorticoids in sensitivity to psychostimulants and may suggest new therapeutic strategies for the treatment of drug addiction.

\section{ACKNOWLEDGMENTS}

This work was supported by the Institut National de la Santé et de la Recherche Médicale (INSERM), University of Bordeaux II, the Conseil Régionata đaAquitaine, the Pôle Médicament d'Aquitaine, and the Ministry of Research and Higher Education.

We would like to thank Dr. T. E. Robinson for his helpful comments on a draft of the manuscript.

\section{REFERENCES}

Biegon A, Rainbow TC, McEwen BS (1985): Corticosterone modulation of neurotransmitter receptors in rat hippocampus: A quantitative autoradiographic study. Brain Res 332:309-314

Caesar PM, Collins GGS, Sandler M (1970): Catecholamine metabolism and monoamine oxidase activity in adrenalectomized rats. Biochem Pharmacol 19:921-926

De Kloet ER, Sybesma H, Reul JMHM (1986): Selective control by corticosterone of serotonin 1 receptor capacity in raphehippocampal system. Neuroendocrinology 42:513-521
Delfs JM, Schreiber L, Kelley AE (1990): Microinjection of cocaine into the nucleus accumbens elicits locomotor activation in the rat. J Neurosci 10:303-310

Deroche V, Piazza PV, Casolini P, Maccari S, Le Moal M, Simon $H(1992)$ : Stress-induced sensitization to amphetamine and morphine psychomotor effects depend on stress-induced corticosterone secretion. Brain Res 598:343-348

Deroche V, Piazza PV, Le Moal M, Simon H (1993): Sensitization to the psychomotor effects of amphetamine and morphine induced by food restriction depends on corticosterone secretion. Brain Res 611:352-356

Deroche V, Marinelli M, Maccari S, Le Moal M, Simon H, Piazza PV (1995): Stress-induced sensitization and glucocorticoids I: sensitization of dopamine-dependent locomotor effects of amphetamine and morphine depends on stress-induced corticosterone secretion. J Neurosci 15:7181-7188

Fibiger HC, Phillips AG (1988): Mesocorticolimbic dopamine systems and reward. Ann NY Acad Sci 537:206-215

Häfstrand A, Fuxe K, Cintra A, Agnati LF, Zini I, Wilkström AC, Okret S, Zhao-Ying Y, Goldstein M, Steinbusch H, Verhofstad A, Gustafsson JA (1986): Glucocorticoid receptor immunoreactivity in monoaminergic neurons in the rat brain. Proc Natl Acad Sci USA 83:9779-9783

Hooks MS, Jones GH, Smith AD, Neill DB, Justice JB Jr. (1991): Response to novelty predicts the locomotor and nucleus accumbens response to cocaine. Synapse 9:121-128

Imperato A, Puglisi-Allegra S, Casolini P, Zocchi A, Angelucci L (1989): Stress-induced enhancement of dopamine and acetylcholine release in limbic structure: Role of corticosterone. Eur J Pharmacol 165:337-339

Kalivas PW, Duffy P, Barrow J (1989): Regulation of the mesocorticolimbic dopamine system by glutamic acid receptor subtypes. J Pharmacol Exp Ther 251:378-387

Kelland MD, Freeman AS, Chiodo LA (1990): Serotoninergic afferent regulation of the basic physiology and pharmacological responsiveness of nigrostriatal dopamine neurons. J Pharmacol Exp Ther 253:803-811

Koob GF, Bloom FE (1988): Cellular and molecular basis of drug dependence. Science 242:715-723

Le Moal M, Simon H (1991): Mesocorticolimbic dopamine network: functional and regulatory roles. Physiol Rev 71:155-234

Majewska MD (1987): Antagonist-type interaction of glucocorticoids with the GABA receptor-coupled chloride channel. Brain Res 418:377-382

Majewska MD, Harrison NL, Schwartz RD, Barker JL, Paul SM (1986): Steroid hormone metabolites are barbiturate-like modulators of the GABA receptors. Science 232:1004-1007

Marinelli M, Piazza PV, Deroche V, Maccari S, Le Moal M, Simon H (1994): Corticosterone circadian secretion differentially facilitates dopamine-mediated psychomotor effect of cocaine and morphine. J Neurosci 14:2724-2731

Martire M, Pistritto G, Preziosi P (1989): Different regulation of serotonin receptors following adrenal hormone imbalance in rat hippocampus. J Neural Transm 78:109-120

Murison R, Overmier JB, Hellhammer DH, Carmona M (1989): Hypothalamo-pituitary-adrenal manipulations and stress ulcerations in rats. Psychoneuroendocrinology 14:331-338

Piazza PV, Le Moal M (1996): Pathophysiological basis of 
vulnerability to drug abuse: Role of an interaction between stress, glucocorticoids, and dopaminergic neurons. Ann Rev Pharmacol Toxicol 36:359-378

Piazza PV, Deminière JM, Le Moal M, Simon H (1989): Factors that predict individual vulnerability to acquisition of amphetamine self-administration. Science 245:1511-1513

Piazza PV, Deminière JM, Maccari S, Le Moal M, Mormède P, Simon H (1991a): Individual vulnerability to drug self-administration: Action of corticosterone on dopaminergic systems as a possible pathophysiological mechanism. In Willner P, Scheel-Krüger J (eds), The Mesolimbic Dopamine System: From Motivation to Action, Chichester; Wiley, pp 473-495

Piazza PV, Maccari S, Deminière JM, Le Moal M, Mormède P, Simon H (1991b): Corticosterone levels determine individual vulnerability to amphetamine self-administration. Proc Natl Acad Sci USA 88:2088-2092

Piazza PV, Rougé-Pont F, Deroche V, Kharouby M, Le Moal M, Simon H (1993): Corticosterone sensitivity to drugs of abuse: Role of dopamine release. Annual Meeting Society for Neuroscience, Abs 760.14

Piazza PV, Marinelli M, Jodogne C, Deroche V, Rougé-Pont F, Maccari S, Le Moal M, Simon H (1994): Inhibition of corticosterone synthesis by metyrapone decreases cocaineinduced locomotion and relapse of cocaine self-administration. Brain Res 658:259-264

Pulvirenti L, Swerdlow NR, Hubner CB, Koob GF (1991): The role of limbic-accumbens-pallidal circuitry in the activating and reinforcing properties of psychostimulant drugs. In Willner P, Scheel-Krüger J (eds), The Mesolimbic Dopamine System: From Motivation to Action, Chichester; Wiley, pp 131-139

Rastogi RB, Singhal RL (1978): Evidence for the role of adrenocortical hormones in the regulation of noradrena- line and dopamine metabolism in certain brain areas. $\mathrm{Br}$ J Pharmacol 62:131-136

Rothschild AJ, Langlais PJ, Schatzberg AF, Miller MM, Saloman MS, Lerbinger JE, Cole JO, Bird E (1985): The effect of a single acute dose of dexamethasone on monoamine and metabolic levels in the rat brain Life Sci 36:2491-2505

Rougé-Pont F, Marinelli M, Le Moal M, Simon H, Piazza PV (1995): Stress-induced sensitization and glucocorticoids II: Sensitization of the increase in extracellular dopamine induced by cocaine depends on stress-induced corticosterone secretion. J Neurosci 15:7189-7195

Sapolsky RM (1990): Glucocorticoids, Hippocampal damage and the glutamatergic synapse. Prog Brain Res 86:12-23

Scheel-Krüger J, Magelund G, Olianas MC (1981): Role of GABA in the striatal output system: Globus pallidus, nucleus entopeduncolaris substantia nigra and nucleus subthalamicus. In Di Chiara G, Gessa GL (eds), GABA and the Basal Ganglia, New York; Raven Press, pp 165-186

Stein BA, Sapolsky RM (1988): Chemical adrenalectomy reduces hippocampal damage induced by kainic acid. Brain Res 473:175-180

Sutanto W, Handelman G, De Bree F, De Kloet ER (1989): Multifaceted interaction of corticosteroids with the intracellular receptors and with membrane GABA-A receptor complex in the rat brain. J Neuroendocrinol 1:243-247

Tischler ME, Henriksen EJ, Cook PH (1988): Role of glucocorticoids in increased muscle glutamine production in starvation. Muscle Nerve 11:752-756

Veals JW, Korduba CA, Symchwicz S (1977): Effect of dexamethasone on monoamine oxidase inhibition by iproniazid in rat brain. Eur J Pharmacol 41:291-299

Wise RA, Rompre PP (1989): Brain dopamine and reward. Ann Rev Psychol 40:191-225 